\begin{abstract}
An Awkward Partner?
Britain's implementation of the Working Time Directive

Forthcoming in Time and Society Alasdair Blair*, John Leopold** and Luchien Karsten***
\end{abstract}

* Senior Lecturer in International Relations, School of International Studies and Law, Coventry University, UK

** Professor and Head of the Department of Human Resource Management, Nottingham Business School, Nottingham Trent University, UK.

*** Associate Professor, Faculty of Management and Organisation, University of Groningen, The Netherlands. 


\title{
An Awkward Partner?
}

\section{Britain's implementation of the Working Time Directive}

\begin{abstract}
The dominance of member states in the field of social policy has been traditionally depicted as one of the main hurdles facing the development of a European social policy. Resistance by national government to the transfer of influence and control over social policy to the European level has been particularly true for Britain. Opposition to various initiatives, such as the Social Charter and Social Chapter has demonstrated this. It is in this context that this article examines Britain's implementation of the Working Time Directive, this being demonstrative of the distinction between member states and the EU in the social policy arena. In this sense, the Working Time Directive is significant not just because of the provisions it brings to British employees, but because it demonstrates the changing nature of the relationship between member states and the EU in the realm of social policy.
\end{abstract}

\section{I}

\section{Introduction}

This article examines the introduction and implementation of the European Working Time Directive in Britain. This piece of legislation stems from the November 1993 agreement signed by the European Union (EU) Council of Ministers concerning the organisation of Working Time (Council, 1993). As is the case for all EU Directives, ${ }^{\text {i }}$ the fundamental aim of such legislation is the provision of a common set of standards throughout all member states. But because Directives provide for member states to individually decide how they will best achieve the aims of the Directive, there accordingly exists room for distinctions to emerge between nations. Thus, although Directives have the overall aim of ensuring an equalapplication of a particular policy in 
each member state, it is often the case that distinctions do materialise as regards the method and content of implementation. Member states thus have a degree of power over the extent to which national policy mirrors the Directive. In this context, while it might appear that the Working Time Directive would produce a common minimum standard of employment conditions throughout the EU, there is significant potential for variation between countries and between organisations within (and between) particular countries. This state of affairs accordingly demonstrates the competing tensions between the desire of the European Commission to establish a common set of social policy standards and the ability for member states to maintain certain distinct national provisions.

This article specifically examines the process of implementation through a comparative analysis of companies based in Britain. Case study material highlights the traditional distinct approach of Britain to industrial relations and labour market regulation compared to other European countries, reflective of a laissez-faire approach based on voluntarism and a limited role for statutory instruments. The article provides a review of British ind ustrial relations policy in the 1980s and 1990s, and demonstrates the extent to which Britain's implementation of the Working Time Directive is representative of the wider shift away from national responsibility in the field of social policy to the EU level. The research draws on comparative data obtained from survey material on company structure, policy co-ordination, hours of work, annual leave, work breaks, record keeping and monitoring. Semi-structured interviews were conducted with managers responsible for implementing the Regulations and with workers' representatives. ${ }^{\text {ii }}$ Information gathered through this medium focused on issues highlighted in the survey material, including policy networks, rest breaks and definitions of Working Time. 


\section{The British Tradition}

Recent hostility by Britain towards the development of a social dimension within the EU can be traced to the unwillingness of the Conservative governments of Margaret Thatcher (1979-1990) and John Major (1990-1997) to accept labour market regulation from Brussels. While they accepted '...the need for proper standards of social provision to underpin the single market', they were '...not prepared to see Community competence spread into industrial relations' (Hurd, 1991:c.1017). This was principally because in the aftermath of Thatcher's election as Prime Minister in 1979 the British labour market underwent a process of rapid transformation. She brought a fresh approach to industrial relations (Crouch, 1991: 326-55); the advocation of free competition manifesting itself into a reduction in the power of trade unions through the deregulation of industrial practices (Moon, 1994: 43-9; Marsh and Rhodes, 1995: 49-54).

A tough negotiating policy on the domestic front was equally apparent at the European level, where Britain used its veto in the Council of Ministers to object to the imposition of binding legis lation. A consequence of this strategy was a reduction in the speed that European social legislation progressed in the early 1980s and demonstrated the power of member states to block EU progress in this policy arena. At the domestic level the Thatcher government embarked on a series of employment reforms as part of an effort to increase the competitiveness of the British economy. This included the replacement of out-of-date ind ustrial practices that she perceived responsible for the economic malaise that engulfed the nation in the 1970s, and reflected a dual desire to curb the powers of trade unions and reassert the position of the employer vis-à-vis the employee (Marsh, 1992). For example, between 1983 and 1993 the number of British 
people working as part-time employees in their main job increased by $31 \%$, contrasting with a drop of $2.2 \%$ in the number of full-time employees (Employment Gazette, 1995: 215; Marullo, 1995: 30). ${ }^{\text {iii }}$ By 1987 British part-time workers were supposedly suffering the worst pay and employment rights in the EC (Low Pay Unit, 1987; The Economist, 1998a).

Changes to the British labour market meant it had the least legislative restrictions within the European Union on what hours could be worked in tandem with when they could be worked throughout the year. To this end, within Britain there were no nationally applied statutory rights to annual paid holidays, no laws governing hours of work, shift working (apart from drivers of certain goods and passenger vehicles), breaks, and no right to be represented by a trade union with regard to Working Time issues (Rojot, 1994: 6). The reality of this situation was that British legislation did not offer the same level of protection to employees as was evident in many other EU states. There therefore existed considerable variations between EU member states as to the regulation of working time and employment practices, of which the British government regarded the lack of stringent laws to be an important factor in creating a flexible labour market.

The overall trend therefore reflected movement towards a labour market with limited regulations, evidenced by British employees having the longest working week in the European Union (Incomes Data Service, Issue 414, June 1996 and Issue 710, April 1996). But more significantly, these developments demonstrated the dominance of member states over social policy. This was in itself considerably influenced by the fact that this was a policy area that government's could exercise considerable authority over in contrast to the majority of domestic policy-making being subject to external pressure, such as environment policy. An ability to exert influence over socialpolicy at 
the domestic level went in tandem with the reality that policy-making in this field was linked to electoral success. Moreover, the ability of government to determine the shape of social policy in the 1980s was further influenced by the relative weakness of the social democratic actors in the political arena. In the case of Britain this was illustrated by the declining fortunes of the Labour Party and a fall in trade union membership and influence, while at the same time there was a relative increase in the power and influence of employers vis-à-vis the employee. To this end, not only was government more receptive to business interests, there was no counterweight to this viewpoint.

The end product of this situation was the emergence of considerable differences in the social policy provisions of European nations, partly because government's themselves acted as considerable obstacles to any Community wide initiatives. To this end, successive attempts to establish a European social policy had been of a limited success. Such developments influenced the new President of the European Commission, Jacques Delors, to propose a European Social Space in 1986, later announcing at the June 1988 Hanover European Council that the Single Market should give the same priority to economic and social objectives (Doogan, 1992). Although most member states shared this objective, Britain was predictably opposed, emphasised by the lack of support given to the Commission's May 1989 preliminary draft of the Social Charter. Britain was later isolated at the December 1989 Strasbourg European Council in not accepting the Social Charter, thereby demonstrating the differences among member states within this policy area. Indeed, Prime Minister Thatcher 'considered it quite inappropriate for rules and regulation about working practices or welfare benefits to be set at the Community level' (Thatcher, 1993: 750).

A hostile stance was subsequently embodied in the then Conservative government objecting to the European Commission's September 1990 proposal for a 
Draft Directive concerning certain aspects of the Organisation of Working Time $(\operatorname{COM}(90) 317,8073 / 90)$. The British government regarded hours of work as a domestic matter for negotiation between employers and employees, and not Brussels (Department for Employment, 1990: 11), though employers were increasingly the more dominant force in this relationship. An anti-activist stance consequently mirrored the traditional British position within industrial relations reform. From the very beginning the government's objection was based on both political and economic principles. In the first instance, the government believed that the Commission's proposals challenged the established position to regulate hours of work at the national level and thus threatened the ability of the state to shape policy. Secondly, the government thought the Directive would reduce the competitiveness and flexibility of the economy; a stance cultured by Britain having received the greatest percentage of all inward investment into the EU in recent years (European Community Direct Investment 1984-1989: 163). Such a viewpoint was reiterated at the December 1991 Maastricht European Council when John Major negotiated an opt-out from the Social Chapter, having insisted that the chapter be removed from the main body of the Treaty text (Blair, 1999a:93-120). The effect of this negotiating outcome, combined with the Maastricht Treaty's emphasis on subsidiarity and the fact that social protection legislation was subject to unanimous voting, meant that social policy initiatives from the Commission could be easily blocked. As Linda Hantrais notes, 'the competence of the Union to take policy decisions had been called into question, and member states had demonstrated that they were not prepared to forego national sovereignty in the interests of greater European social solidarity’ (Hantrais, 2000: 219).

The British government's opposition to the Working Time Directive was subsequently highlighted within the House of Commons and at meetings of the EU 
Social Affairs Council (Shephard, 1992). A combative stance did, nevertheless, produce some concessions, namely: the right for employees to work more than 48 hours per week and the right for employers and employees to make collective agreements on working time at a local level. ${ }^{\text {iv }}$ But such developments failed to satisfy the Conservative government of the day, prompting it to challenge the Directive's legal basis in the European Court of Justice after the Council reached a political agreement on a common position in June 1993 (Forsyth, 1993). That challenge proved unsuccessful, having been based on an assumption that the Directive was wrongly implemented via the health and safety provisions of the SEA (Article 118A) which permitted decisions to be taken by majority voting, and thereby overruling British opposition. $^{\mathrm{v}}$ This was specifically because the government considered that those areas of social policy not embraced by the Maastricht opt-out should be subject to unanimous voting. But this was a view not shared by the Court of Justice, with the Advocate-General's March 1996 opinion against the UK and its subsequent confirmation in November by the European Court of Justice consequently angering the British government (Advocate General, 1996; European Court of Justice, 1996). In its judgement the Court specifically noted that the concepts of 'working environment', 'safety' and 'health' within the provision comprise 'all factors, physical or otherwise, capable of affecting the health and safety of the worker in his working environment' (European Court of Justice, 1996: para 15).

The significance of the Court's decision was that it demonstrated a movement to establish social policy at the European level that could not be hindered by member state obstruction. In so doing it went some way to readdress the balance in favour of member states as confirmed by the Maastricht Treaty, with the Court's decisions having become an important means of establishing a more harmonious system of social policy 
(Leibfried and Pierson, 2000: 276). The European Court of Justice has thus offered a fresh path to renewed activism in the area of social policy. This is against a backdrop of member state obstruction to European Commission initiatives and a lack of consens us within the Council of Ministers as to the best way forward in the area of social policy. Of the reasons for this, one of the most important is that the European Court of Justice does not suffer from the same political horse-trading that is a common feature in European Union negotiations, while the voting procedure of the Court only requires a simple majority vote.

A consequence of the European Court's decision on Working Time was that the Conservative government had to immediately start the process of implementing the Directive at the national level. But it similarly championed the reversal of the Court's decision at the European level whereby Ministers advocated the importance of national control of working hours at EU meetings. This was marked by the Department of Trade and Industry publishing in December 1996 a Consultation Document on Measures to Implement Provisions of the EC Directive on the Organisation of Working Time (DTI, 1996). The government also announced that a key negotiating policy within the 1996-97 Intergo vernmentalConference (IGC) would be a tightening of Article 118 A to remove the Directive's applicability (Lang, 1996). This threat was, of course, influenced by a real desire to retain national control over social policy legislation.

At this time it is worth remembering that the wider political climate was dominated by the imminent general election, which brought victory for New Labour in May 1997. Committed to the Directive's implementation in opposition, it was nevertheless just short of a year before draft-implementing measures were issued by the Labour government on 8 April 1998, with the provision that individuals could work longer hours if they wished (DTI, 1998a). At the end of July 1998 the government put 
the final version before Parliament, with there having been very little discussion within the Palaces of Westminster on this subject. ${ }^{\mathrm{vi}}$ This document, which included a small number of changes to the original consultation text, paved the way for the Directive to enter force within Britain from 1 October 1998. ${ }^{\text {vii }}$ This was one month short of two years after the Directive became force within the EU and despite the government having been open to legal action because of the failure to implement the Directive by November 1996, only a few cases emerged. It can therefore be seen that while the Thatcher government considered the setting of social policy regulations to be a domestic matter outwith the scope and competence of the then European Community, the reality of this state of affairs was no longer true. In this sense, the Working Time Directive highlighted that member states are no longer able to fully control the social policy arena, though they are nevertheless able to exercise considerable influence in this policy field.

\section{III}

\section{The Politics of Implementation}

Labour's election to office immediately created a more constructive relationship between Britain and the EU, demonstrated by acceptance of the Social Chapter at the June 1997 Amsterdam European Council meeting. Despite signalling the coming of a reformist government in the area of industrial relations, this decision was nevertheless based on the Treaty of Amsterdam's new Employment Chapter reflecting a flexible method of governance in the social policy arena (Hughes and Smith, 1998:96-7). This move was symptomatic of the government's desire not to impose strict regulations on labour market practices: the new Employment Chapter represented a flexible strategy more akin to British than French (regulatory) views. Such a strategy was linked to 
Labour's election to office, which was based upon a centrist and anti-interventionist policy aimed at middle-class voters. This has been reflected in the absence of close links between trade unions and the government, being instead replaced by a 'fairness not favours' style of policy-making whereby trade unions and employer organisations equally discuss matters with government.

The politics of this duel are evident over the Working Time Directive, which the Labour Party committed itself to implementing upon election to office. The outcome of this is that British employees are now governed by a set of conditions that include a maximum working week of 48-hours; a requirement for breaks throughout the day, at the end of the day and every week or fortnight; a provision for paid annual holidays; the regulation of night shift working; and the creation of a specific set of conditions for young workers (see box 1). But while the government publicly championed the Directive as a distinction between it and the Conservative Party, it was also notable that the Labour government asked for and obtained derogations in many of the policy areas covered by the Directive. Such a strategy was considered a means of pacifying the interest of business and pressure groups such as the Institute of Directors and Confederation of British Industry.

Such use of derogations both mirrors and stands opposite to the practice of the previous Conservative government. Thus, the ability for workers to qualify for three weeks' paid annual leave after 13 weeks' work is markedly different from the Conservative government's plan for workers to qualify for the three-week holiday after 49 weeks' service (Regulations 13-16). ${ }^{\text {vii }}$ Furthermore, while the Labour government proposed that the rest break permitted after six-hours work should be at least 20 minutes (and should count as part of working time), the Conservative government had advocated that the rest break need be no longer than five minutes. In addition, although 
the Conservative government proposed that only employment tribunals would enforce the Directive, Labour decided to involve the health and safety enforcing authorities and local authorities. To this end, while newspaper headlines have focused upon the maximum working week of 48-hours and the provision for eight-hour night shifts, the regulations are of a wider ranging nature and have knock-on effects for many full-time and agency workers. Thus, the legislation empowers employees with new powers, including health assessments for night workers and the provision of contemporary rest breaks for those who do not qualify for a break. The latter includes security guards, an industry where some of the worst employment practices exist.

\section{Box 1:}

\section{Key provisions of the Working Time Regulations}

- Maximum weekly working time of 48 hours (including overtime) a veraged over 17 weeks.

- A minimum of 11 consecutive hours rest period per 24-hour period.

- A minimum weekly uninterrupted rest period of 24 hours, plus a daily rest period of 11 hours - amounting to 35 hours in total.

- A rest break for workers whose working day is longer than six hours (details to be worked out by collective agreement).

- A normal maximum working time of 8 hours in any 24 for night workers and an actual maximum working time of 8 hours in any 24 for night workers whose work involves special hazards or heavy physical or mental strain.

- A minimum period of leave of 3 weeks per year, rising to 4 by 23 November 1999.

Of the exemptions, the Labour government provided the ability for employees to work more than 48 hours a week if they so wished, ${ }^{\text {ix }}$ while the Regulations initially limited holiday provision to three weeks paid leave (rather than the four weeks provided for in the Directive). This increased to four weeks in November 1999. The provision for paid holiday leave is nevertheless weakened by the ability for public holidays to be included in the three (four)-week holiday entitlement. It can therefore be seen that the scope and coverage of the Regulations are somewhat limited by the ability 
for employees to continue to work long hours, while the holiday entitlement is less significant because of the ability to count public holidays.

The significance of these exemptions is that while the Regulations provide added employment protection to the employee, the government has left considerable room for manoeuvre as to the extent of the applicability of these conditions. Chief among these was the ability for employees to work more than 48 hours a week if they so wished, with this option being aimed at white-collar middle-managers in the service sector who have a tendency to work long hours. This in itself was not that a surprising development as the Trades Union Congress and the CBI were aware that it would be difficult for all employees to suddenly shift working patterns to less than 48 hours. But what was surprising was that the government did not attempt to establish a negotiated reduction in working hours, bearing in mind that the ability to work in excess of 48 hours per week is an option to be reviewed by the European Commission in 2003 .

In this sense, the fact that some British employees work in excess of 48 -hours per week is not the primary distinction between Britain and other EU nations. Indeed, despite the presence of the Directive throughout the EU, long-hours are features of many white-collar jobs in all member states. For instance, while survey material established that the Dutch banking industry negotiated a maximum working week of 36-hours in 1995, many of the managers interviewed commented that they too had hours of work that were in excess of 48 per week (EIRR, 2000). ${ }^{\mathrm{x}}$ The reason why this is so is that such employees tend to work the hours that the job requires because of future ambitions of promotion and concerns of job insecurity. Where a distinction can be made, however, is that there is an absence of social partner involvement in the reduction of working hours in Britain. What is evident from this research is that although there was some initial confusion over working hours, the maximum working week has posed 
few problems. This is because a great many working patterns are within the 48 -hour weekly limit, while those employees who do work in excess of this limit often have the ability to be exempt from the Regulations. For instance, all the companies interviewed for this research had contracted working hours ranging from 35 to 40 hours per week, although managers privately recognised that they tended to work longer hours.

In analysing the Labour government's strategy of implementation, it is evident that there was both a desire to maintain a flexible labour market and an unwillingness to set comprehensive Regulations. The implication of this strategy was that specific decisions on Working Time could be taken at local level, though the provision for a flexible interpretation produced confusion among employers and employees as to the scope and coverage of the Regulations. The direct result of this was that organisations such as the Advisory, Conciliation and Arbitration Service (ACAS) received a dramatic increase in the number of telephone enquiries, of which a significant proportion concerned working time (see appendix 1). Moreover, of those calls relating to working time received by the ACAS East Midlands office, the biggest area of concern related to annual leave and maximum weekly working time (see table 1). This was equally apparent from the companies surveyed for this research. Such statistics are therefore demonstrative of the confusion created by the absence of defined guidelines.

Table 1:

Working Time Regulations record of calls received by ACAS East Midlands office

\begin{tabular}{|l|l|l|l|l|l|l|l|l|}
\hline Month & $\begin{array}{l}\text { Max. } \\
\text { weekly } \\
\text { working } \\
\text { time }\end{array}$ & $\begin{array}{l}\text { Rest } \\
\text { breaks }\end{array}$ & $\begin{array}{l}\text { Daily } \\
\text { rest } \\
\text { period } \\
\text { period } \\
\text { rest }\end{array}$ & $\begin{array}{l}\text { Night } \\
\text { work }\end{array}$ & $\begin{array}{l}\text { Annual } \\
\text { leave }\end{array}$ & Other & Total \\
\hline $\begin{array}{l}\text { Oct. } \\
\mathbf{1 9 9 8}\end{array}$ & 174 & 78 & 50 & 49 & 61 & 607 & 226 & 1245 \\
\hline $\begin{array}{l}\text { Nov. } \\
\mathbf{1 9 9 8}\end{array}$ & 104 & 48 & 35 & 24 & 27 & 552 & 149 & 939 \\
\hline $\begin{array}{l}\text { Dec. } \\
\mathbf{1 9 9 8}\end{array}$ & 46 & 40 & 21 & 12 & 13 & 442 & 132 & 706 \\
\hline Jan. & 55 & 41 & 26 & 18 & 14 & 668 & 103 & 925 \\
\hline
\end{tabular}




\begin{tabular}{|l|l|l|l|l|l|l|l|l|}
\hline $\mathbf{1 9 9 9}$ & & & & & & & & \\
\hline $\begin{array}{l}\text { Feb. } \\
\mathbf{1 9 9 9}\end{array}$ & 66 & 48 & 25 & 15 & 23 & 698 & 123 & 998 \\
\hline $\begin{array}{l}\text { Mar. } \\
\mathbf{1 9 9 9}\end{array}$ & 78 & 62 & 35 & 22 & 15 & 973 & 163 & 1348 \\
\hline $\begin{array}{l}\text { Apr. } \\
\mathbf{1 9 9 9}\end{array}$ & 64 & 63 & 28 & 12 & 15 & 918 & 140 & 1242 \\
\hline $\begin{array}{l}\text { May. } \\
\mathbf{1 9 9 9}\end{array}$ & 35 & 45 & 27 & 16 & 11 & 760 & 99 & 977 \\
\hline
\end{tabular}

\section{IV}

\section{Conclusion}

The Britishexperience of implementing the Working Time Directive is reflective of the traditional unwillingness of successive governments to fully accept the intrusion of European policy on domestic affairs. The Conservative governments of the 1980 s and 1990s certainly marked a high point of this awkwardness when dealing with European issues. During those years, Britain encountered a dramatic change in industrial relations policy, whereby labour markets were deregulated and employment became measured by its degree of flexibility. Much of these reforms assisted in Britain attracting the greatest amount of inward investment of all EU nations, though many other EU governments considered that an absence of labour market regulation in Britain represented an unfair competitive advantage. One effect of these changes to the British labour market was an increase in unemployment rates, with many of the new part-time 'flexible' service sector jobs not replacing the traditional full-time manufacturing occupations. For those individuals who remained in employment, job security became increasingly fragile, which in the presence of few restrictions on employment conditions resulted in longer working weeks, especially among white-collar middle management positions. The election of the Labour government in May 1997 was expected by the electorate to result in some form of change to industrial 
relations policy within Britain. To be sure, the Working Time Regulations sit alongside the establishment of a Minimum Wage as evidence of this. Significantly, however, both policies pay as much attention to business interests as employee protection.

This situation demonstrates the constraints imposed on government at the national level from different interest groups, such as trade unions and employer representatives. But while it might appear that governments are able to shape policy objectives that are reflective of these interests, it is in fact the case that the capacity for domestic decision-making is greatly determined by the further progression of EU integration. To this end, the ability of member states to exercise independent financial authority (tax and spend) is constrained by developments at the EU level. For instance, member state progression to monetary union has taken place within the context of the need to meet the four economic convergence criteria, which for some member states, such as Italy, has limited the amount of money the government could spend on social protection measures. It is therefore evident that changes within the EU, such as monetary union, do limit the ability of member states to exercise independent sovereignty.

But whereas this scenario demonstrates the closer linkages and the diminishing levels of state sovereignty within the EU, it is also evident that resistance by member states to Europe-wide developments is bound by the EU's institutional structure, particularly the dominance of the European Court of Justice. In this context, Britain's implementation of the Working Time Directive is demonstrative of the constraints imposed on government by the Court. And although the British government chose to make some slight adjustments to the terms of the Directive, it did so from a tightly controlled list. So the options for government's to be awkward when implementing such legislation has diminished, being shaped by the diminishing level of national 
sovereignty within the EU. And this scenario of integration being driven more by the decisions of the Court rather than the efforts of the Commission is likely to be the main method of making further advances in the social policy arena (Leibfried and Pierson, 2000). 
Appendix 1:

Calls answered by ACAS East Midlands office

\begin{tabular}{|l|l|l|}
\hline Month & Total Calls Answered & $\begin{array}{l}\text { Number of calls relating } \\
\text { to Working Time }\end{array}$ \\
\hline April 1998 & 3366 & \\
\hline May 1998 & 3018 & \\
\hline June 1998 & 3462 & \\
\hline July 1998 & 3463 & \\
\hline August 1998 & 3068 & \\
\hline September 1998 & 4082 & \\
\hline October 1998 & 4807 & 1245 \\
\hline November 1998 & 4400 & 939 \\
\hline December 1998 & 3520 & 706 \\
\hline January 1999 & 4994 & 925 \\
\hline February 1999 & 5515 & 998 \\
\hline March 1999 & 6727 & 1348 \\
\hline April 1999 & 5928 & 1242 \\
\hline May 1999 & 4937 & 977 \\
\hline
\end{tabular}




\section{References}

Advocate General (1996) Opinion of Advocate General Leger delivered on 12 March 1996, Case C-84/94, United Kingdom v Council of the European Union (Council Directive 93/104/EC of 23 November 1993 concerning certain aspects of the organisation of working time - Action for annulment).

Barnard, C., Clark, J. and Lewis, R. (1995), The Experience of Individual Employment Rights in the Member States of the European Community, Department for Employment Research Series No.49, April.

Blair, A. (1999a) Dealing with Europe: Britain and the Negotiation of the Maastricht Treaty, Aldershot: Ashgate.

Blair, A. (1999b) 'Time Please', Parliamentary Brief, Vol.6, No.2, November, p.26.

Blair, A. (2000) 'New Labour: New Social Policy', Talking Politics, Summer, Vol.13, No.1, pp.4-8,

Blair, A.; Karsten, L,; Leopold, J. (2001) 'Britain and the Working Time Regulations', Politics, Vol.21, No.1, February.

Council (1993) 93/104 Council Directive/EC of 23 November 1993 concerning certain aspects of the organisation of working time.

Crouch, C. (1991) 'United Kingdom: The Rejection of Compromise', in Guido Baglioni and Colin Crouch (ed) European Industrial Relations: The Challenge of Flexibility, London: Sage.

Department for Employment (1987) Consultative Document, Restrictions on Employment of Young People and the Removal of Sex Discrimination in Legislation, December, London: HMSO.

Department for Employment (1990) Consultative Document, Commission's Draft Directives on part-time and Temporary Work and Working Time, 3 August, London: HMSO.

Doogan, K. (1992) 'The Social Charter and the Europeanisation of the Employment and Social Policy, Policy and Politics, vol.20, no.3.

DTI (1996) Department of Trade and Industry, Consultation Document on Measures to Implement Provisions of the EC Directive on the Organisation of Working Time, December.

DTI (1998a) Department of Trade and Ind ustry, Measures to Implement Provisions of the EC Directive on the Organisation of Working Time ('The Working Time Directive') and the Protection of Young People at Work ('The Young Workers Directive'): Public Consultation, URN: 98/645.

DTI (1998b) Department of Trade and Industry, Regulatory Guidance: Working Time Conditions, (http://www.dti.gov.uk/ER/WTR/).

DTI (1998c) Department of Trade and Ind ustry, Fairness at Work, Cm 3968. London: Department of Trade and Industry.

Edwards, P. (1995) 'Strikes and Industrial Conflict', in P. Edwards (ed) Industrial Relations: Theory and Practice, Oxford: Blackwell, pp.434-460.

EEF (1998) Engineering Employers Federation, Implementing the Working Time Regulations: A Practical Guide. London, Engineering Employers Federation.

EIRR (2000) European Industrial Relations Review 'Working time: An Anglo-Dutch Comparison', Issue 312, January 2000, pp.17-20.

Employment Gazette (1995) 'An analysis of working time 1979-1994', vol.10, no.5. European Community Direct Investment 1984-1989 (1992), Luxembourg: Office for Official Publications of the EC. 
European Court of Justice (1996) Judgement of the Court, 12 November, in Case C-84/94, United Kingdom of Great Britain and Northern Ireland v Council of the European Union.

Forsyth, M. (1993) House of Commons Official Report, 7 June, c.95 written.

Gilmour, I. (1993) Dancing with Dogma: Britain under Thatcherism, London: Pocket Books.

Hall, M., Lister, R. and Sisson, K. (1998) The New law on Working Time: Managing the Implications of the 1998 Working Time Regulations. University of Warwick, Industrial Relations Group.

Hantrais, L. (2000) Social Policy in the European Union, Basingstoke: Macmillan.

Horrell, S. and Rubery, J. (1991) Employers' Working Time-Policies and Women's Employment, (Equal Opportunities Commission Research Series). London: HMSO.

Hurd, D. (1991) House of Commons Official Report, vol.193, 26 June.

Joseph Rowntree Foundation (1996) Parenting in the 1990s, Social Policy Research Report.

Lang, I. (1996) House of Commons Official Report, 12 November, c.156.

Leibfried, S. and Pierson, P. (2000) 'Social Policy: Left to Courts and Markets', in Helen Wallace and William Wallace, Policy-Making in the European Union, $4^{\text {th }}$ edition, Oxford: Oxford University Press.

Low Pay Unit (1987) Part-timers Under Pressure, London: Low Pay Unit.

Marsh, D. (1992) The New Politics of British Trade Unionism: Union Power and the Thatcher Legacy, Basingstoke: Macmillan.

Marsh, D. and Rhodes, R.A.W. (1995) 'Over the Moon or as Sick as a Parrot?', Politics, vol.15, no.1.

Marullo, S. (ed) (1995) Comparisons of Regulations on Part-Time and Temporary Employment in Europe (A briefing paper), Research Series No.52. London: Department for Employment.

Metcalf, D. (1991) 'British Unions: Dissolution or Resurgence', Oxford Review of Economic Policy, Vol.7, No.1, pp.18-32.

Moon, J. (1994) 'Evaluating Thatcher: Sceptical versus Synthetic Approaches', Politics, vol.14, no.2.

NHS Executive (1998), Working Time Regulations: Implementation in the NHS, Health Service Circular, Series No. HSC 1998/204, 19 November. Wetherby: Department of Health.

Piotet, F. (1988) The Changing Face of Work: Researching and Debating Issues. European Foundation for the Improvement of living and Working Conditions. Luxembourg: Office for Official Publications of the EC.

Prior, J. (1986) A Balance of Power, London: Hamish Hamilton.

Rhodes, M. (1991) 'The Social Dimension of the Single European Market: National versus Transnational Interests', European Journal of Political Research, vol.19.

Rojot, J. and Blanpain, R. (1994) Legal and contractual limitations to working time in the European Union member states: general report, European Foundation for the improvement on Living and Working Conditions.

Rubery, J. (1998) 'Working time in the UK, Transfer, Vol.4, No.4, Winter, pp.657-677.

Shephard, G. (1992) House of Commons Official Report, 30 June, c.548 written.

Thatcher, M. (1993) The Downing Street Years, London: Harper Collins.

UK (1998) Statutory Instrument 1998 No.1833: The Working Time Regulations 1998.

London: HMSO (http//www.hmso.gov.uk/si/si1998/19981833.htm).

UK (1999) Employment Relations Bill. London: HMSO. 


\section{Notes}

We are grateful to the companies and organisations that assisted with this research, Professor Linda Hantrais of Loughborough University for commenting on an initial draft of this paper, the helpful comments of two anonymous referees and the assistance of Dr Mike Crang for improving the focus of the paper.

${ }^{\mathrm{i}}$ Directives are one of the four main acts which are adopted by the Council and the European Commission, the others being regulations, decisions and recommendations. Directives are a legal instrument requiring me mber states to adopt appropriate ru les, although they are left with the choice as to how to achieve the objectives.

${ }^{\text {ii }}$ Interviews were conducted between March and June 1999 with companies that represented different sectors of the labour force that had a tradition of a long hour culture and shift working: Abbey National Bank; British Nursing Association; Group 4 Security; Ikea; J. Sainsbury; Marks and Spencer, Novotel; Powergen; Raleigh Cycles; and Van den Bergh Foods. Interviews were also conducted with the Advisory, Conciliation and Arbitration Service (acas); Confederation of British Industry (CBI); and the Trades Union Congress (TUC). Interviews with the latter two provided information on the degree to which they were consulted by government as to the content of the Regulations, and the feedback obtained from their members as to the experience of implementing the Regulations. Material obtained from ACAS demonstrated the degree to which employers and employees sought clarification as to the scope and coverage of the Regulations.

iii There has generally been a strong fiscal incentive to employ part-time and self-employed workers in Britain because emp loyers have not had to pay national insurance contributions on part-time earnings until they reach a given threshold, whilst not having to pay national insurance contributions at all for the self-employed. The introduction of the equal treatment directive has, however, meant that such distinctions are no longer applicable.

iv The limitations of the Directive apply to 'working time'. This is defined as 'any period which the worker is working, at the employer's disposal and carrying out his practices, or duties, in accordance with national laws and/or practice' (Article 2, para 1).

${ }^{v}$ The government had taken the view that there was not 'real' evidence to link working time with health and safety, and that as the working time conditions were es sentially dealing with working conditions then they should have been dealt with through unanimity voting.

${ }^{v i}$ See, for example, Early Day Motions 1601 1997/98 in the name of David Chidgey and 1637 1997/98 in the name of Christopher Gill.

vii The Regulations, which implement the Working Time Directive and the EC Young Workers Directive, have been made under section 2(2) of the European Communities Act 1972. See Council Directive 94/33/EC of 22 June 1994 on the p rotection of young people at work. For an overv iew of the Regulations see: 'The Working Time Regulations 1998', Incomes Data Service Brief No.620, September 1998, pp.10-17.

viii While the leave can be taken in instalments, it has to be taken in the leave year in question and cannot be replaced by pay in lieu, apart from if the worker leaves the job early with leave owing. If a worker leaves their job having actually taken more leave than their pro rata entitlement, then a relevant agreement can stipulate that they should provide some sort of compensation to their employer. There are no exceptions to this provision.

${ }^{\text {ix }}$ Regulation 4 provides a basic limit of 48 -hours to the working week to be averaged over 17 weeks, although the working week can be additionally averaged over 26 weeks in a special case. The provisions for a 48-hour working week to be averaged over a 17 week reference period can also be extended to up to 52 weeks by collective agreement or by workforce agreement

${ }^{\mathrm{x}}$ Interview: Secretary General Dutch Employers Banking Federation, 23 June 1999. 